\title{
2,6-Diaminopimelic acid as a biological marker of rumen synthesis and fermentation capacities in the transition period and early lactation of dairy cows
}

\author{
Iveta Maskal’ová, Vladimír Vajda, Lukáš Bujňák \\ University of Veterinary Medicine and Pharmacy in Košice, Department of Animal Nutrition, Dietetics \\ and Animal Breeding, Slovak Republic \\ Received January 17, 2014 \\ Accepted July 23, 2014
}

\begin{abstract}
The experiment was conducted to evaluate the effect of different types of available nutrients of total mix rations on fermentation and synthesis capacities of the rumen in Holstein dairy cows divided into groups in the transition period ( \pm 3 weeks after parturition) and early lactation (60-80 days in milk). The diets were fed as a total mixed ration. Results obtained with feeding Diet $\mathrm{C}$ (high concentration of available nutrients) to dairy cows confirmed a significant increase in 2,6-diaminopimelic acid from the initial mean $2.2 \mu \mathrm{g} / \mathrm{ml}$ at 21 days before calving to $6.2 \mu \mathrm{g} / \mathrm{ml}$ $(P<0.01)$ at 21 days after calving or $7.6 \mu \mathrm{g} / \mathrm{ml}(P<0.01)$ at early lactation, and a parallel significant increase in the concentration of volatile fatty acids $(P<0.01)$. The concentration of propionic acid increased from the initial mean 25.3 to $39.3 \mathrm{mmol} / \mathrm{l}(P<0.01)$ in the transition period, and to $43.1 \mathrm{mmol} / \mathrm{l}$ at early lactation $(P<0.01)$. All indicators of rumen fermentation and synthesis determined in dairy cows with Diet B (low concentration of available nutrients) of the total mix ration according to productive phases were not significant. High regression coefficients of examined indicators of 2,6-diaminopimelic acid to volatile fatty acid $(\mathrm{r}=0.813)$, propionic acid $(\mathrm{r}=0.780)$ and acetic acid $(r=0.635)$ indicate direct correlation between fermentation and synthesis activities of the rumen. Our results show that 2,6-diaminopimelic acid appears as a perspective marker for the monitoring and evaluation of the synthesis function of the rumen and production of bacterial biomass under breeding conditions.
\end{abstract}

VFA, DAPA, feeding and nutrition, microflora, fermentation

Rumen fermentation of the feed's organic matter and microbial biomass synthesis are reported to have the potential to meet $70-85 \%$ of the energy requirements and $70-100 \%$ of the protein needs of ruminants, even at higher levels of production. Microbial proteins synthesized in the rumen cover $80 \%$ of daily amino acid needs and constitute $50-80 \%$ of total absorbable amino acids (Bach et al. 2005). Synthesis of microbial proteins is affected by usability of fermentable carbohydrates (Ahvenjarvi et al. 2002), nitrogen (Verbic 2002) and minerals (Broudiscou et al. 1999). Optimum production of rumen microflora and synthesis of microbial proteins at the level of $12.6 \mathrm{~g} / 100 \mathrm{~g}$ fermentable organic matter is ensured when the concentration of $\mathrm{NH}_{3}$ in the ruminal fluid varies in the range $8.8-14.7 \mathrm{mmol} / \mathrm{l}$ which is an accepted reference value for assessment of the level of protein saturation in ruminant rations (Vajda et al. 1994; NRC 2001). Microbial efficiency expressed as $\mathrm{g}$ of microbial nitrogen per $\mathrm{kg}$ of dry matter, organic matter, total carbohydrate, and $100 \mathrm{~g} \mathrm{~N}$ digested, ranged from 20.8 to $26.6 ; 34.7$ to $44.3 ; 35.1$ to 50.3 and 89 to $95 \mathrm{~g}$, respectively (Sniffen et al. 2006). Multiplication and growth of rumen microflora is affected by nutritional (quantity and ratio of carbohydrates and proteins) and dietetic factors (structure of total mix ration, dry matter intake, production of saliva). These factors are directly related to rumen $\mathrm{pH}$, intensity and type of fermentation, osmolality, passage and evacuation of solids and liquids (Dehority 2004). Quantification of synthesis of microbial proteins is an important part of the evaluation of biological control of the nutritional level of high yielding dairy cows. Several methods have been developed for

Address for correspondence:

Iveta Maskal'ová

Department of Animal Nutrition, Dietetics and Animal Breeding

University of Veterinary medicine and Pharmacy in Košice

Phone: +421915986726

Komenského 73, 04181 Košice, Slovak Republic 
the determination of microbial protein in the rumen contents. These methods fall into two categories: methods for tracing bacterial protein or those based on the analysis of marker components believed to be uniquely microbial in origin. In particural, 2,6-diaminopimelic acid (DAPA) was accepted as a reliable marker for determining microbial protein (MinerWilliams et al. 2013). It is a well known peptidoglycan amino acid bound to bacterial cell walls of gram-negative bacteria (Ling 1990). Gram-positive bacteria contain approximately $30-60 \%$ peptidoglycan, whereas gram-negative bacteria have only $10 \%$ peptidoglycan (Schoenhusen et al. 2008). Amino acid composition and structure of peptidoglycans in gram-positive bacteria varies greatly, whereas that of gram-negative bacteria is more consistent (Miner-Williams et al. 2013). Knowledge of the DAPA concentration in the walls of bacterial cells is the basis for verification of the hypothesis of the possibility of applying DAPA in the rumen content as a marker of the synthesis of bacterial biomass.

The aim of the study was to investigate the influence of ration composition on the level and dynamics of rumen fermentation of carbohydrates and degradation of proteins in relation to the synthesis of microbial proteins by observing 2,6-diaminopimelic acid.

\section{Materials and Methods}

The feeding experiment was carried out as two consecutive experiments on dairy cows with diets varying in the sources of rumen available carbohydrate and protein, to analyze the influence of the nutrient level on fermentation and synthesis capacity of the rumen. Diets were formulated using the NRC (2001). Eighteen multiparous Holstein dairy cows $(600 \pm 12.5 \mathrm{~kg}$ body weight $(\mathrm{BW}) ; 2.9 \pm 0.3$ parity) were studied during three periods: 1) from day 21 before expected calving; 2) from calving up to day 21 of lactation; 3) day 60 to day 80

Table 1. Ingredients and chemical composition of TMR - Diet C.

\begin{tabular}{|c|c|c|c|c|}
\hline & & 3 week before calving & 3 weeks after calving & 60-80 DIM \\
\hline Corn silage & $\mathrm{kg}$ & 5.0 & 9.0 & 9.0 \\
\hline Alfalfa haylage & $\mathrm{kg}$ & 6.0 & 8.0 & 8.0 \\
\hline Grass hay & $\mathrm{kg}$ & 1.5 & - & - \\
\hline Alfalfa hay & $\mathrm{kg}$ & - & 3.0 & 3.0 \\
\hline Barley silage & $\mathrm{kg}$ & 5.0 & 9.0 & 9.0 \\
\hline Barley straw & $\mathrm{kg}$ & 0.5 & - & - \\
\hline Grain mixture & $\mathrm{kg}$ & 3.0 & 7.0 & 7.0 \\
\hline Corn grain & $\mathrm{kg}$ & 2.0 & 5.0 & 5.0 \\
\hline Amygold & $\mathrm{kg}$ & 1.0 & 3.0 & 3.0 \\
\hline DM & $\%$ & 39.4 & 51.1 & 56.2 \\
\hline $\mathrm{CP}$ & $\mathrm{g} / \mathrm{kg}$ of $\mathrm{DM}$ & 131.9 & 153.9 & 170.3 \\
\hline NDF & $\mathrm{g} / \mathrm{kg}$ of $\mathrm{DM}$ & 471.1 & 359.6 & 309.1 \\
\hline NFC & $\mathrm{g} / \mathrm{kg}$ of $\mathrm{DM}$ & 314.5 & 381.7 & 405.2 \\
\hline Starch & $\mathrm{g} / \mathrm{kg}$ of $\mathrm{DM}$ & 236.7 & 272.7 & 279.7 \\
\hline NEL & $\mathrm{MJ} / \mathrm{kg}$ of $\mathrm{DM}$ & 6.24 & 6.98 & 7.31 \\
\hline \multicolumn{5}{|c|}{ Daily intake of nutrients } \\
\hline$\overline{\mathrm{DM}}$ & $\mathrm{kg}$ & 11.7 & 17.0 & 23.6 \\
\hline $\mathrm{CP}$ & $\mathrm{g}$ & 1543.2 & 2614.6 & 4019.1 \\
\hline $\mathrm{NDF}$ & $\mathrm{g}$ & 5511.9 & 6113.2 & 7294.8 \\
\hline NFC & g & 3679.7 & 6488.9 & 9562.7 \\
\hline Starch & g & 2769.4 & 4635.9 & 7011.6 \\
\hline NEL & MJ & 73.01 & 118.7 & 172.5 \\
\hline
\end{tabular}

TMR - total mixed ration, DM - dry matter, CP - crude protein, NDF - neutral detergent fibre, NFC - non-fibre carbohydrates, NEL - net energy for lactation, MJ - mega joule, DIM - days in milk, Amygold - corn gluten feed (Beuker) 
Table 2. Ingredients and chemical composition of TMR - Diet B.

\begin{tabular}{|c|c|c|c|c|}
\hline & & 3 week before calving & 3 weeks after calving & 60-80 DIM \\
\hline Grass silage & $\mathrm{kg}$ & 10.0 & 15.0 & 15.0 \\
\hline Corn silage & $\mathrm{kg}$ & 5.0 & 15.0 & 15.0 \\
\hline Hay & $\mathrm{kg}$ & 1.0 & 1.0 & 1.0 \\
\hline Rindavit $^{2}$ & $\mathrm{~kg}$ & 0.2 & - & - \\
\hline Grain mixture & $\mathrm{kg}$ & 3.0 & 7.0 & 7.0 \\
\hline DM & $\%$ & 53.2 & 41.9 & 43.1 \\
\hline $\mathrm{CP}$ & $\mathrm{g} / \mathrm{kg}$ of DM & 97.5 & 149.1 & 140.2 \\
\hline $\mathrm{NDF}$ & $\mathrm{g} / \mathrm{kg}$ of $\mathrm{DM}$ & 570.3 & 426.1 & 432.8 \\
\hline NFC & $\mathrm{g} / \mathrm{kg}$ of $\mathrm{DM}$ & 191.1 & 311.1 & 312.4 \\
\hline Starch & $\mathrm{g} / \mathrm{kg}$ of $\mathrm{DM}$ & 180.9 & 257.1 & 262.5 \\
\hline NEL & $\mathrm{MJ} / \mathrm{kg}$ of $\mathrm{DM}$ & 5.40 & 6.37 & 6.34 \\
\hline \multicolumn{5}{|c|}{ Daily intake of nutrients } \\
\hline $\mathrm{DM}$ & $\mathrm{kg}$ & 11.9 & 15.0 & 17.0 \\
\hline $\mathrm{CP}$ & $\mathrm{g}$ & 1160.3 & 2236.5 & 2453.5 \\
\hline $\mathrm{NDF}$ & g & 6785.6 & 6391.5 & 7574.0 \\
\hline NFC & g & 2274.1 & 4666.5 & 5467.0 \\
\hline Starch & $\mathrm{g}$ & 2152.7 & 3856.5 & 4593.7 \\
\hline NEL & MJ & 64.3 & 95.5 & 110.9 \\
\hline
\end{tabular}

TMR - total mixed ration, DM - dry matter, $\mathrm{CP}$ - crude protein, NDF - neutral detergent fibre, NFC - non-fibre carbohydrates, $\mathrm{NEL}$ - net energy for lactation, MJ - mega joule, DIM - days in milk, Rindavit - the vitamin/mineral premix (Schaumann)

in milk. Cows were housed in box stalls and milked in these stalls at 06:00 h and 18:00 h. Diets were fed as a total mixed ration (TMR) ad libitum at 07:00 h and 19:00 h. The ingredient and chemical composition of the diets and daily intake of nutrients are presented in Tables 1 and 2 . The TMR for different groups of cows was calculated to meet the demands for energy and protein of the cow $(600 \mathrm{~kg}$ of BW) producing $21 \mathrm{~kg}$ of milk/d with an assumed dry matter intake (DMI) of $16 \mathrm{~kg}$ of dry matter/day (DM/d) in the second group, and $32 \mathrm{~kg}$ of milk/d and $21 \mathrm{~kg}$ DMI in the third group. The diets varied in sources of rumen available carbohydrate and protein (Diet C - high concentration of available nutrients, Diet B - low concentration of available nutrients). Samples of TMR were analyzed for dry mater, crude protein (CP), acid and neutral detergent fibre (ADF, NDF), and starch according to conventional methods (Committee Regulation EC No.152/2009 of January 27, 2009). Dry matter was determined by weight upon drying the sample at $105{ }^{\circ} \mathrm{C}$ under prescribed conditions. The $\mathrm{CP}$ content was determined according to the Kjeldahl methods $(\mathrm{N} \times 6.25)$ using a 2300 Kjeltec Analyser Unit (Foss Tecator AB, Hoganas, Sweden). The ADF and NDF were determined by the device Dosi-Fibre Analyzer (JP SELECTA, Spain) and non-fibre carbohydrates (NFC) were calculated by difference (100- (CP + (NDF-NDF bound protein) + ash + ether extract))

Analysis of VFA and $\mathrm{NH}_{3}$

Samples of the rumen contents intended for the analysis of fermentation and synthesis capacity of the rumen were taken $4-5 \mathrm{~h}$ after morning feeding by stomach cannulas. Samples of rumen fluid were strained through 3-layer of gauze. VFA in the rumen contents were determined in a two-capillary isotachophoretic analyser EA100 (VILLA LABECO, Slovak Republic). The $\mathrm{pH}$ of the rumen contents was determined potentiometrically with portable electronic $\mathrm{pH}$-meter (JP SELECTA, Spain). The concentration of $\mathrm{NH}_{3}$ in samples of rumen contents was determined by a Kjeldahl-N using a 2300 Kjeltec Analyser Unit (Foss Tecator AB, Hoganas, Sweden).

Analysis of 2,6-diaminopimelic acid (DAPA)

After acidic hydrolysis of the sample of ruminal contents, DAPA was determined by means of AAA 400 (INGOS, Czech Republic). Immediately after sampling, the samples were conserved with addition of thymol. They were stored in a portable refrigerator and transported to the laboratory for examination within $1 \mathrm{~h}$. Before processing, the samples were refrigerated for $1 \mathrm{~h}$ and filtered through 3-layer gauze. Then a $10 \mathrm{ml}$ aliquot of rumen contents was pipetted into a hydrolysation flask and $50 \mathrm{ml}$ of $6 \mathrm{~N} \mathrm{HCl}$ were added. Hydrolysis was carried out for $23 \mathrm{~h}$ in a thermostat at $110-112^{\circ} \mathrm{C}$. After $23 \mathrm{~h}$, the hydrolysation reagent was evaporated in a vacuum 
rotating evaporator using an oil vacuum pump. The content of DAPA was determined by the method of ion exchange chromatography with post-column derivatisation with ninhydrine, using an analyser of amino acid AAA 400 (INGOS, Czech Republic).

The results achieved were processed by mathematical-statistical methods involving the statistical program GraphPad Prism4. We evaluated values and their differences using Tukey-HSD test at significance levels of $P \leq 0.01$ and $P \leq 0.05$, respectively. Each indicator was presented by its mean (x) and standard deviation (S.D.).

\section{Results}

\section{Diet C (high concentration of available nutrients)}

In the group of dairy cows in the period of nutritional adaptation for parturition, analyses showed that the content of all nutrients in TMR corresponded to the recommended values with the exception of increased NDF. The intake of nutrients corresponded to the profile of rumen fermentation of carbohydrates (Table 3) with mean values of $\mathrm{pH} 6.4 \pm 0.1$ and VFA $110.1 \pm 5.4 \mathrm{mmol} / \mathrm{l}$. The proportions of acetic acid $\left(\mathrm{C}_{2}\right)$ and propionic acid $\left(\mathrm{C}_{3}\right)$ reached $66.1 \pm 2.9 \%$ and $22.9 \pm 3.2 \%$, respectively, and their ratio was $2.91: 1\left(\mathrm{C}_{2}: \mathrm{C}_{3}\right)$, which reflected a high degree of adaptation of rumen fermentation in the phase of preparation for the intake of the concentrate type of rations after parturition. The intake and rumen degradation of CP maintained the concentration of $\mathrm{NH}_{3}$ in the rumen close to the lower reference limit and the content of DAPA at $2.2 \pm 0.3 \mu \mathrm{g} / \mathrm{ml}$.

Table 3. Indicators of rumen fermentation and 2,6-diaminopimelic acid in rumen content of dairy cows.

\begin{tabular}{|c|c|c|c|c|c|}
\hline Indicator & & $\begin{array}{l}\text { 1-3 weeks } \\
\text { pre partum }\end{array}$ & $\begin{array}{c}1-3 \text { weeks } \\
\text { post partum }\end{array}$ & $\begin{array}{l}60-80 \mathrm{DIM} \\
\text { post partum }\end{array}$ & Summary \\
\hline \multirow[t]{2}{*}{ DAPA $\mu \mathrm{g} / \mathrm{ml}$} & $\mathrm{C}$ & $2.2 \pm 0.3^{\mathrm{a}, \mathrm{b}}$ & $6.2 \pm 1.1^{\mathrm{a}}$ & $7.6 \pm 2.7^{b}$ & $5.3 \pm 2.9$ \\
\hline & $\mathrm{B}$ & $1.8 \pm 0.5$ & $1.9 \pm 0.4$ & $1.9 \pm 0.8$ & $1.9 \pm 0.6$ \\
\hline \multirow[t]{2}{*}{$\mathrm{pH}$} & $\mathrm{C}$ & $6.4 \pm 0.1^{\mathrm{i}}$ & $6.1 \pm 0.3^{\mathrm{h}}$ & $5.6 \pm 0.2^{\mathrm{h}, \mathrm{i}}$ & $6.0 \pm 0.4$ \\
\hline & $\mathrm{B}$ & $6.9 \pm 0.2$ & $6.8 \pm 0.1$ & $6.96 \pm 0.4$ & $6.9 \pm 0.3$ \\
\hline \multirow[t]{2}{*}{$\mathrm{NH}_{3} \mathrm{mmol} / 1$} & $\mathrm{C}$ & $10.5 \pm 2.3^{\mathrm{j}, 1}$ & $15.2 \pm 2.7^{\mathrm{j}, \mathrm{k}}$ & $21.5 \pm 3.6^{\mathrm{k}, \mathrm{l}}$ & $15.7 \pm 5.3$ \\
\hline & $\mathrm{B}$ & $3.5 \pm 0.6$ & $8.6 \pm 2.1$ & $8.6 \pm 1.6$ & $6.9 \pm 2.9$ \\
\hline \multirow[t]{2}{*}{ VFA mmol/1 } & $\mathrm{C}$ & $110.1 \pm 5.4^{\mathrm{c}, \mathrm{e}}$ & $127.7 \pm 8.7^{\mathrm{c}, \mathrm{d}}$ & $148.4 \pm 12.6^{\mathrm{d}, \mathrm{e}}$ & $128.7 \pm 18.3$ \\
\hline & $\mathrm{B}$ & $86.5 \pm 14.3$ & $106 \pm 6.2$ & $87.9 \pm 22.9$ & $93.5 \pm 18.3$ \\
\hline \multirow[t]{2}{*}{ Acetic acid \% } & $\mathrm{C}$ & $66.1 \pm 2.9$ & $56.3 \pm 3.3$ & $58.2 \pm 3.4$ & $60.2 \pm 5.3$ \\
\hline & $\mathrm{B}$ & $70.5 \pm 2.0$ & $67.7 \pm 1.3$ & $68.2 \pm 2.7$ & $68.8 \pm 2.4$ \\
\hline \multirow[t]{2}{*}{ Propionic acid \% } & $\mathrm{C}$ & $22.9 \pm 3.2$ & $30.7 \pm 2.8$ & $29.0 \pm 1.6$ & $27.5 \pm 4.2$ \\
\hline & $\mathrm{B}$ & $18.9 \pm 2.4$ & $20.8 \pm 1.3$ & $19.8 \pm 2.5$ & $19.9 \pm 2.3$ \\
\hline \multirow[t]{2}{*}{$\overline{C_{2}: C_{3}}$} & $\mathrm{C}$ & $2.91: 1$ & $1.9: 1$ & $2.02: 1$ & $2.28: 1$ \\
\hline & B & $3.8: 1$ & $3.3: 1$ & $3.52: 1$ & $3.52: 1$ \\
\hline
\end{tabular}

C - Diet C (high concentration of available nutrients), B - Diet B (low concentration of available nutrients), DAPA 2,6-diaminopimelic acid, VFA - volatile fatty acid, C2 -acetic acid, C3 - propionic acid, DIM - days in milk, a,e,g,i,l: $P<0.001$, b.c.f: $P<0.01, \quad$ d,h,k,j: $P<0.05$

\section{Group of post partum dairy cows}

In the puerperal stage up to 21 days postpartum, the obtained results indicated a high degree of rumen fermentation and optimum adaptation to the diet $\mathrm{C}$ (resp. concentrate type rations). The high concentration of VFA reaching $127.7 \pm 8.7 \mathrm{mmol} / \mathrm{l}$ at marginal levels of rumen $\mathrm{pH} 6.1 \pm 0.3$, decreased proportion of $\mathrm{C}_{2} 56.3 \pm 3.3 \%$, and increased level of $\mathrm{C}_{3} 30.7 \pm 2.8 \%$ resulting in their decreased ratio of $1.9: 1\left(\mathrm{C}_{2}: \mathrm{C}_{3}\right)$, confirmed appropriate fermentation of the concentrate type TMR. The concentrations of $\mathrm{NH}_{3}$ determined in the 
rumen contents $(15.2 \pm 2.7 \mathrm{mmol} / \mathrm{l})$ were close to the upper reference limit and correlated with the proportion of proteins in TMR, which indicated saturation of needs for CP required for multiplication of rumen microflora, and the concentration of DAPA $(6.2 \pm 1.1 \mu \mathrm{g} / \mathrm{ml})$ showed a highly significant $(P<0.01)$ increase.

\section{Group of dairy cows at early lactation}

These animals were fed the concentrate type of TMR with a $40 \%$ content of NFC and $30 \%$ content of starch, and showed very high level of rumen fermentation. The mean values of VFA reaching $148.4 \pm 12.6 \mathrm{mmol} / \mathrm{l}$, rumen $\mathrm{pH}$ at the level of $5.6 \pm 0.2$, proportions of $\mathrm{C}_{2}$ and $\mathrm{C}_{3}$ at $58.2 \pm 3.4 \%$ and $29.0 \pm 1.6 \%$, respectively, and their mutual ratio of $\left(\mathrm{C}_{2}: \mathrm{C}_{3}\right)$ 2.02 : 1 signalled chronic rumen acidosis while maintaining rumen fermentation capacity. At early lactation, in addition to increased synthesis capacity of the rumen expressed as DAPA reaching $7.6 \pm 2.7 \mu \mathrm{g} / \mathrm{ml}$ we were able to observe an increased $\mathrm{NH}_{3}$ concentration of $21.5 \pm 3.6 \mathrm{mmol} / \mathrm{l}(P<0.01)$ signalling secondary degradation of microbial proteins conditional on a decrease of $\mathrm{pH}$ and deterioration of conditions for the survival of rumen microflora. The results of examination of rumen metabolism in relation to the nutrient intake according to productive stages proved a significant increase in DAPA from the mean initial pre partum concentration of $2.2 \mu \mathrm{g} / \mathrm{ml}$ to $6.2 \mu \mathrm{g} / \mathrm{ml}(P<0.01)$ at 21 days post partum and $7.6 \mu \mathrm{g} / \mathrm{ml}(P<0.01)$ at early lactation in parallel with a significant increase in VFA from the pre partum concentration of $110.1 \mathrm{mmol} / 1$ to $127.7 \mathrm{mmol} / 1$ post partum $(P<0.01)$ and $148.4 \mathrm{mmol} / \mathrm{l}$ at early lactation $(P<0.0001)$. The concentration of propionic acid increased from the pre partum level of $25.3 \mathrm{mmol} / 1$ to $39.3 \mathrm{mmol} / \mathrm{l}(P=0.0022)$ post partum and to $43.1 \mathrm{mmol} / \mathrm{l}(P<0.01)$ at early lactation.

\section{Diet B (low concentration of available nutrients)}

Low intake of energy $(5.4 \mathrm{MJ} / \mathrm{kg})$ and of CP equal to $9.7 \%$ in TMR dry matter in the phase of preparation for parturition affected essentially the level of rumen fermentation. High level of $\mathrm{pH} 6.9 \pm 0.2$, limited production of VFA $(86.5 \pm 14.3 \mathrm{mmol} / \mathrm{l})$, increased proportion of acetic acid $70.5 \pm 2.0 \%$ and reduction in propionic acid to $18.9 \pm 2.4 \%$ with high ratio of $\mathrm{C} 2$ : $\mathrm{C} 3$ equal to 3.8 : 1 confirmed that rumen fermentation corresponded to Diet B with the mean values of DAPA at $1.8 \pm 0.5 \mu \mathrm{g} / \mathrm{ml}$. In the post partum stage and at early lactation the dairy cows were fed unified rations whose composition during the productive phase (CP 14-15\%, NEL 6.3 MJ and PDI $88 \mathrm{~g} / \mathrm{kg}$ ) corresponded to Diet B (low concentration of available nutrients, or bulk type of TMR). The indicators of rumen fermentation in the post partum phase and at early lactation indicated that degradation of carbohydrates (VFA, $\mathrm{pH}, \mathrm{C}_{2}: \mathrm{C}_{3}$ ), concentration of $\mathrm{NH}_{3}$, and synthesis capacity of rumen microflora (DAPA) corresponded to a low nutrient intake reflecting the degree of fermentation (Table 3). All the indicators of fermentation and rumen synthesis analyzed with TMR of Diet B, according to production phases, showed insignificant differences.

\section{Relationship between fermentation and synthesis capacities of rumen microflora}

Regression relationships of the investigated concentrations of DAPA, VFA, propionic and acetic acids, and their ratios were obtained by mutual comparison of results determined for concentrate and bulk type rations according to production phases. Evaluation of the relationship between VFA and DAPA proved a direct regression relationship with high regression coefficient $(\mathrm{r}=0.813)$. In relation to the nutrient content of the analyzed rations the correlation confirmed existence of a direct relationship between fermentation activity - production of VFA and the synthesis activity and development of rumen microflora with DAPA as its direct cellular marker. When analyzing the relationship between individual VFA and the level of DAPA in the rumen contents of dairy cows, the highest correlation was found 
for propionic acid with a linear regression $\mathrm{r}=0.780$, and for both acetic acid and DAPA with a regression coefficient $r=0.635$. The $\mathrm{C}_{2}: \mathrm{C}_{3}$ ratio calculated from the concentrations of the respective volatile fatty acids allowed us to characterize the fermentation model in relation to DAPA in the rumen contents and to obtain the regression coefficient $r=0.734$.

\section{Discussion}

The time of sample collection has no effect on the content of DAPA in bacteria, and the ratio of DAPA-N concentration to total $\mathrm{N}$ concentration in mixed rumen bacteria after feeding remains relatively constant (Dufva et al. 1982). Our observations of the relationship between markers of the fermentation (VFA, $\mathrm{pH}$ ) and synthesis activities of the rumen (DAPA) were therefore carried out at the time of maximum rumen fermentation of carbohydrates and degradation of proteins, and samples of ruminal fluid were taken 4-6 $\mathrm{h}$ after feeding. The present model feeding experiment investigated relationships between the fermentation and synthesis capacities for bulky and concentrate types of rations. The determined concentrations of DAPA, together with the levels of VFA, $\mathrm{pH}$ and rumen $\mathrm{NH}_{3}$, corresponded to marginally increased levels with tendency to acidification.

Rumen synthesis of microbial proteins depends considerably on the quantity and type of ingested carbohydrates contained in the ration as a source of energy for the synthesis of peptide bonds and growth of micro-organisms (Sinclair et al. 1995). Olubobokun et al. (1988) observed that the concentration of DAPA in the ruminal fluid was higher compared to rumen microflora which adheres to feed particles. A portion of DAPA from the rumen liquid fraction is not precipitated even by centrifugation at higher speed which proves that it occurs in the form of very small particles as a part of fragments of cellular walls produced at microbial lyses and degradation of bacterial proteins.

Bacterial lyses of rapidly growing population which increase the concentration of DAPA result in overrating the synthesis capacity of microbial proteins (Gomez et al. 1991). Our observations indicated such a state of rumen metabolism in groups of animals with tendency towards rumen acidification in which we observed also high concentrations of $\mathrm{NH}_{3}$ and DAPA. Feeding the concentrate type of rations with a higher content of VFA, low rumen $\mathrm{pH}$ and altered ratio of propionic and acetic acids reflects higher quantity of substrates from fermentation which supports dominance of amylolytic population and suppresses celulolytic population. Higher proteolytic activity is typical for amylolytic microflora compared to celulolytic strains (Wallace 1987) which explains higher degradation of proteins with an increasing concentration of DAPA. Low rumen $\mathrm{pH}$, approaching the limit of subclinical acidosis, supports multiplication of Streptococcus bovis.

It was assumed that $S$. bovis does not contain DAPA (Dufva et al. 1982). Later analyses proved the presence of DAPA in S. bovis (Russell and Robinson 1984) which at concentrate feed rations and low $\mathrm{pH}$ may increase the rumen content of DAPA in dairy cows. The growth phase of microflora is the time of incubation and differs from availability of substrates and type of microbial strains that are manifested by varying microbial synthesis (Blümmel et al. 2003). Because of those different concentrations it may reflect various types of micro-organisms within the rumen population, different ratios of protozoa and bacteria, bacteria in liquid and solid phases of the rumen contents and also various stages of growth of respective microbial populations. The diverse bacterial populations within rumen microflora are characterized by different cellular walls and peptidoglycan layers which are reflected in varying concentrations of DAPA in the rumen contents (E1Waziry et al. 2005).

Increasing proportion of the concentrate feed in rations increases the abundance of gram positive bacteria with relatively thick peptidoglycan layer. The DAPA-N : total bacterial $\mathrm{N}$ ratio differs within bacterial species in dependence on the type of rations (Dufva et al. 
1982). The natural variability of DAPA proportion in individual microbial strains limited the wider use of DAPA as a biological marker of growth of microbial population. The 2,6-diaminopimelic acid appears as a perspective marker for monitoring and evaluation of the synthesis function of the rumen and production of bacterial biomass under breeding conditions.

\section{Acknowledgements}

The study was supported by the Scientific Grant Agency of the Ministry of Education of the Slovak Republic (Grant KEGA No. 016UVLF-4/2012).

\section{References}

Ahvenjarvi S, Vamhatalo A, Huhtanen P 2002: Supplementing barley or rapeseed meal to dairy cows fed grassred clover silage.1. Rumen degradability and microbial flow. J Anim Sci 80: 2176-2187

Bach A, Calsamiglia S, Stern MD 2005: Nitrogen metabolism in the rumen. J Dairy Sci 88: 9-21

Blümmel M, Karsil A, Russel JR 2003: Influence of diet on growth yields of rumen micro-organisms in vitro and in vivo: influence on growth yield of variable carbon fluxes to fermentation products. Brit J Nutrit 90: 625-634

Broudiscou LP, Papon Y, Broudiscou AF 1999: Effects of minerals on feed degradation and protein synthesis by rumen microbes in a dual effluent fermenter. Reprod Nutri Devel 39: 255-268

Committee regulation EC No.152/2009, 2009: Committee Regulation (EC) EC No.152/2009 of 27 January 2009 laying down the methods of sampling and analysis for the official control of feed, OJ L 54, 26/02/2009, $130 \mathrm{p}$.

Dehority BA 2004: Rumen Microbiology. Nottingham, University Press, 372 p.

Dufva GS, Bartley EE, Arambel MJ, Nagaraja TG, Dennis SM, Galitzer SJ, Dayton AD 1982: Diaminopimelic acid content of feeds and rumen bacteria and its usefulness as rumen bacterial marker. J Dairy Sci 65: 1754-1759

El-Waziry Ahmed M, Onodera R, Ling JR 2005: Determination of total and separate stereoisomers of diaminopimelic acid in five species and mixed rumen bacteria using high-performance liquid chromatography. Res J Agri Biol Sci 1: 67-71

Gomez L, Bogaert C, Jouany JP, Lassalas B 1991: The influence of lasalocid and cationmycin on nitrogen digestion in sheep: Comparison of methods for estimating microbial nitrogen. Can J Anim Sci 71: 389-399

Ling JR 1990: Digestion of bacterial cell walls in the rumen. In: Hoshino S, Onodera R, Minato H, Itabashi H (Eds). The Rumen Ecosystem: The Microbial Metabolism and its Regulation. Springer - Verlag, New York, pp. $83-90$

Miner-Williams W, Moughan PJ, Fuller MF 2013: Comparison of three markers for the determination of bacterial protein in terminal ileal digesta in the growing pig. J Anim Physiol Anim Nutr (Berl) 97: 951-959

National Research Council (NRC) 2001: Nutrient Requirements of Dairy Cattle: $7^{\text {th }}$ rev. ed. National Academy of Sciences, Washington DC, $401 \mathrm{p}$.

Olubobokun JA, Craig WM, Nipper WA 1988: Characteristics of protozoan and bacterial fractions from microorganisms associated with ruminal fluid or particles. J Anim Sci 66: 2701-2710

Russell JB, Robinson PH 1984: Compositions and characteristics of strain of Streptococcus bovis. J Dairy Sci 67: $1525-1531$

Schoenhusen U, Voigt J, Hennig U, Kuhla S, Zitnan R, Souffrant W B 2008: Bacterial D-alanine concentrations as a marker of bacterial nitrogen in the gastrointestinal tract of pigs and cows. Vet Med-Czech 53: 184-192

Sinclair LA, Garnsworthy PC, Newbold JR, Buttery PJ 1995: Effects of synchronizing the rate of dietary energy and nitrogen release in diets with a similar carbohydrate composition on rumen fermentation and microbial protein synthesis in sheep. J Agric Sci Cambr 124: 463-472

Sniffen CJ, Ballard CS, Carter MP, Cotanch KW, Dann HM, Grant RJ, Mandebvu P, Suekawa M, Martin SA 2006: Effects of malic acid on microbial efficiency and metabolism in continuous culture of rumen contents and on performance of mid-lactation dairy cows. Anim Feed Sci Tech 127: 13-31

Vajda V, Bindas L', Demeterová M, Magic D 1994: Veterinary Dietetics (in Slovak). VVŠL Košice, 345 p.

Verbic J 2002: Factors affecting microbial protein synthesis in the rumen with emphasis on diets containing forages. Bericht 29. Viehwirtschaftliche Factgang, BAL, Gumpenstien, April 24-25, pp. 1-6

Wallace RJ, McPherson CA 1987: Factors affecting the rate of breakdown of bacterial protein in rumen fluid. Brit J Nutri 58: 313-323 